\title{
Suitability analysis Of Tanjung Benoa Waters- Bali for dive tourism
}

\author{
Dwi Budi Wiyanto ${ }^{1,2}$, Nuddin Harahab $^{2}$, Rudianto ${ }^{2}$, and Aida Sartambul ${ }^{2}$ \\ ${ }^{1}$ Study Program of Marine Science, Faculty of Marine Science and Fisheries, Udayana University, \\ Bukit Jimbaran, Bali 80361, Indonesia \\ ${ }^{2}$ Faculty of Fisheries and Marine Science, Universitas Brawijaya, Malang, Indonesia
}

\begin{abstract}
This study was aimed to evaluate the suitability of Tanjung Benoa waters for dive tourism. The suitability analysis was carried out using Suitability Tourism Index (STI) method. Water visibility, coral reef coverage, lifeform, coral fish, water depth, and water current were used to analyze the suitability rate. The result showed that Tanjung Benoa waters were categorized as appropriate conditional (STI $=40.74$ to 42.59 ). The less appropriate condition at the location might be caused by the high anthropogenic activities in the land.
\end{abstract}

\section{Introduction}

Tanjung Benoa water is one of the most popular marine tourism in Bali Island. Scuba diving is one of many marine tourism activities beside Snorkeling and Seawalker [5]. Coral reef and coral fish are the common attractants in a marine tourism [16]. Marine ecosystem in Bali Island is reported to have high diversity and abundant, since it is located in a tropical region. However, most of them are unexplored [14]. There is lack information about the environmental condition in the Tanjung Benoa waters. Therefore, it is necessary to evaluate the suitability of this area. A suitable environmental condition is required to be ensured in a location to be used as a dive tourism spot.

Several parameters are known to be used as parameter to evaluate the suitability of an area for dive tourism. Coral reef coverage, life form, and coral fish are some of the important factors for the life coral. Correspond to the coral reef, coral fish is usually associated with the coral [6]. Therefore, these parameters are important to be ensured in a good condition for dive tourism. The other factors associated with the existence of coral reefs in a marine ecosystem are: water visibility, water depth, and water current [12]. Water visibility is important for the life of the coral reef, because a high rate of water visibility is associated with the growth and photosynthesis carried out by the zooxanthellae $[3,19]$. Water current and water depth is important for the safety of scuba diver, because it is related with the decompression risk [11]. Therefore, this study is aimed to evaluate the suitability of Tanjung Benoa waters to be used as a dive tourism area. 


\section{Materials and Method}

\subsection{Site location}

This study was carried out in the Tanjung Benoa waters, Bali, Indonesia. Observation of the environmental condition in coral reef ecosystem was carried out in 4 different sites. The sites are mentioned in the Table 1 and Figure 1.

Table 1. Coordinate of sampling locations

\begin{tabular}{ccc}
\hline Location & Latitude & Longitude \\
\hline Site 1 & $8^{\circ} 45^{\prime} 32.71^{\prime \prime}$ & $115^{\circ} 13^{\prime} 26.34^{\prime \prime}$ \\
Site 2 & $8^{\circ} 45^{\prime} 40.78^{\prime \prime}$ & $115^{\circ} 13^{\prime} 28.84^{\prime \prime}$ \\
Site 3 & $8^{\circ} 45^{\prime} 46.60^{\prime \prime}$ & $115^{\circ} 13^{\prime} 30.10^{\prime \prime}$ \\
Site 4 & $8^{\circ} 45^{\prime} 54.42^{\prime \prime}$ & $115^{\circ} 13^{\prime} 29.72^{\prime \prime}$ \\
\hline
\end{tabular}

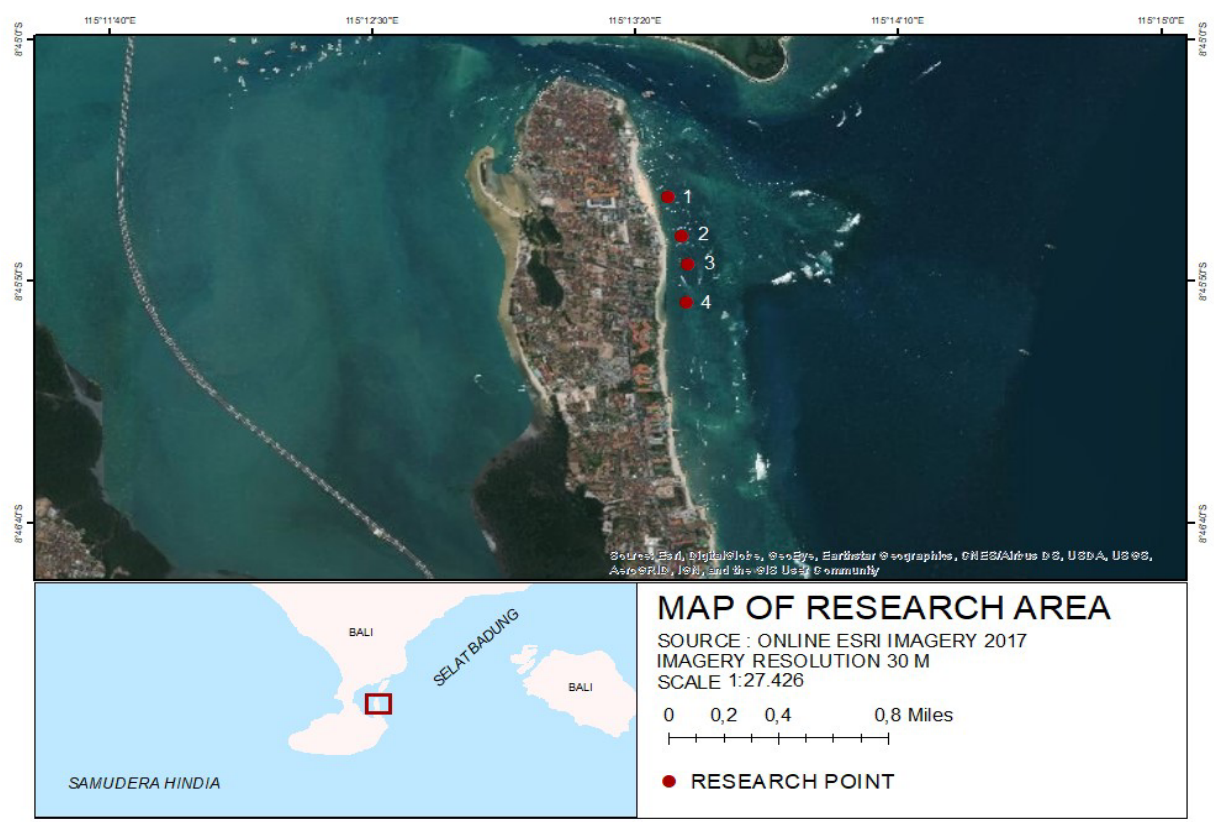

Figure 1. Map of research location in Tanjung Benoa, Bali

\subsection{Measurement of the physical parameters of water}

The physical parameters measured in this study were: water visibility (\%), water depth $(\mathrm{m})$, and water current velocity $(\mathrm{m} / \mathrm{s})$. Both of water visibility and water depth were measured using sechi disc, while the water current was measured using current meter.

\subsection{Sampling technique}

Observation of the coral benthic was carried out using line intercept transect (LIT) method [20]. The line was laid on the beach up to 100 meters of the beach line to the shore. This 
transect was placed on the 5-7 meter of water depth. Data was provided by noted the shape of the coral growth, biotic, and abiotic inside of the transect.

\subsubsection{Percentage of coral reef coverage}

The percentage of hard coral live (HCL) was used to estimate the coral reef condition in a marine environment. The percentage of life-coral was provided using formula:

$$
L i=\frac{n i}{L} \times 100 \%
$$

Where: $L i$ was the percentage of coverage, $n i$ was the total length of biota group, and $L$ was the total length of the transect line $(100 \mathrm{~m})$. The criteria for coral reef condition were determined based on the list in the Table 2 .

Table 2. Criteria of the life-coral coverage [8]

\begin{tabular}{cll}
\hline \multicolumn{1}{c}{ Parameter } & \multicolumn{2}{c}{ Standard for the coral damage (\%) } \\
\hline \multirow{3}{*}{ Percentage of coral coverage $(\%)$} & Poor & $0-24.9$ \\
\cline { 2 - 3 } & Fair & $25-49.9$ \\
\cline { 2 - 3 } & Very good & $50-74.9$ \\
\cline { 2 - 3 } & Excellent & $75-100$ \\
\hline
\end{tabular}

\subsubsection{Coral fish}

The observation of the coral fish was carried out using the direct visual census method [4]. The number of species and individuals of coral fish was observed in 2,5 $\mathrm{m}$ of the left and right of the observer along the transect. Every site was equipped with a $100 \mathrm{~m}$ sized transect as the guideline of the data collection (based on the Line Intercept Transect-LIT method). During the observation, the observed fish was documented using an underwater camera and identified using a manual for coral fish identification $[15,19]$.

\subsection{Data analysis}

The suitability analysis was carried out by considering 6 environmental parameters into 4 score (Table 3).

Table 3. Scoring of the suitability analysis for the dive tourism [22]

\begin{tabular}{lccccccccc}
\hline \multirow{2}{*}{ Parameter } & Sc & \multicolumn{9}{c}{ Category } \\
\cline { 3 - 10 } & & $\mathbf{A}$ & $\begin{array}{c}\text { Sc } \\
\mathbf{A}\end{array}$ & $\mathbf{Q A}$ & $\begin{array}{c}\text { Sc. } \\
\text { QA }\end{array}$ & $\mathbf{A C}$ & $\begin{array}{c}\text { Sc. } \\
\mathbf{A C}\end{array}$ & \multirow{2}{*}{ NA } & Sc. \\
\hline Water visibility (\%) & 5 & $>80$ & 3 & $50-80$ & 2 & $20-<50$ & 1 & $<20$ & 0 \\
HCL (\%) & 5 & $>75$ & 3 & $>50-75$ & 2 & $25-50$ & 1 & $<25$ & 0 \\
Coral life form & 3 & $>12$ & 3 & $<7-12$ & 2 & $4-7$ & 1 & $<4$ & 0 \\
Coral fish & 3 & $>100$ & 3 & $50-100$ & 2 & $20-<50$ & 1 & $<20$ & 0 \\
Water depth (m) & 1 & $6-15$ & 3 & $15-20$ & 2 & $>20-30$ & 1 & $>30$ & 0 \\
Water current (m/s) & 1 & $0-15$ & 3 & $>15-30$ & 2 & $>30-50$ & 1 & $>50$ & 0 \\
\hline
\end{tabular}

A: Appropriate; QA: Quite appropriate; AC: Appropriate conditional; NA: Not Appropriate; Sc: Score [10]. 
Determination of area suitability was carried out using following formula:

$$
\text { Suitability Tourism Index }(S T I)=\sum\left[\frac{N_{i}}{N_{\max }}\right] \times 100 \%
$$

Where: $S T I$ is the suitability rate of the area, $N i$ is the score of variable $i, N_{\max }$ is the maximum score for a tourism category.

Suitable area was determined by multiplying the score $(S c)$ obtained from each parameter. The rate of suitability was provided from the total score of all parameters. The area suitability rate then categorized into four groups as mentioned in Table 4.

Table 4. Category of suitability rate [22]

\begin{tabular}{cll}
\hline No & Range & Category \\
\hline 1 & Index $>75 \%$ & Very appropriate \\
2 & $50-75 \%$ & Quite appropriate \\
3 & $25-50 \%$ & Appropriate conditional \\
4 & Index $<25 \%$ & Not appropriate \\
\hline
\end{tabular}

\section{Results}

\subsection{Environmental condition of coral reef}

The result showed that the water visibility in the Tanjung Benoa Waters at all sites was ranging from 56 to $62 \%$. The percentage of HCL were ranging from 0,47 to $23,70 \%$, and the highest was shown at Site $3(23,70 \%)$. Observation in the coral life form showed that the highest amount of coral life form was shown at Site 3 (11 individual), but there was no big difference with other sites. Correspond to the amount of coral life form, the highest number of coral fish species was shown at Site 3 (14 species). Water depth shows no significant difference between sites $(6,5-6,8)$ as well as its current velocity. The environmental condition of coral reef in the Tanjung Benoa waters is shown in Table 5 and Figure 2.

Table 5. Environmental condition of coral reef in the Tanjung Benoa waters

\begin{tabular}{lcccc}
\hline \multirow{2}{*}{ Category } & \multicolumn{3}{c}{ Site } \\
\cline { 2 - 5 } & 1 & 2 & 3 & 4 \\
\hline Water visibility (\%) & 57 & 62 & 59 & 56 \\
Percentage of HCL (\%) & 3,13 & 14,28 & 23,70 & 0,47 \\
Coral lifeform (individual) & 10 & 9 & 11 & 9 \\
Coral fish species (species) & 9 & 8 & 14 & 8 \\
Water depth (m) & 6,8 & 6,5 & 6,6 & 6,5 \\
Water current (m/s) & 1,2 & 0,9 & 0,8 & 1,3 \\
\hline
\end{tabular}



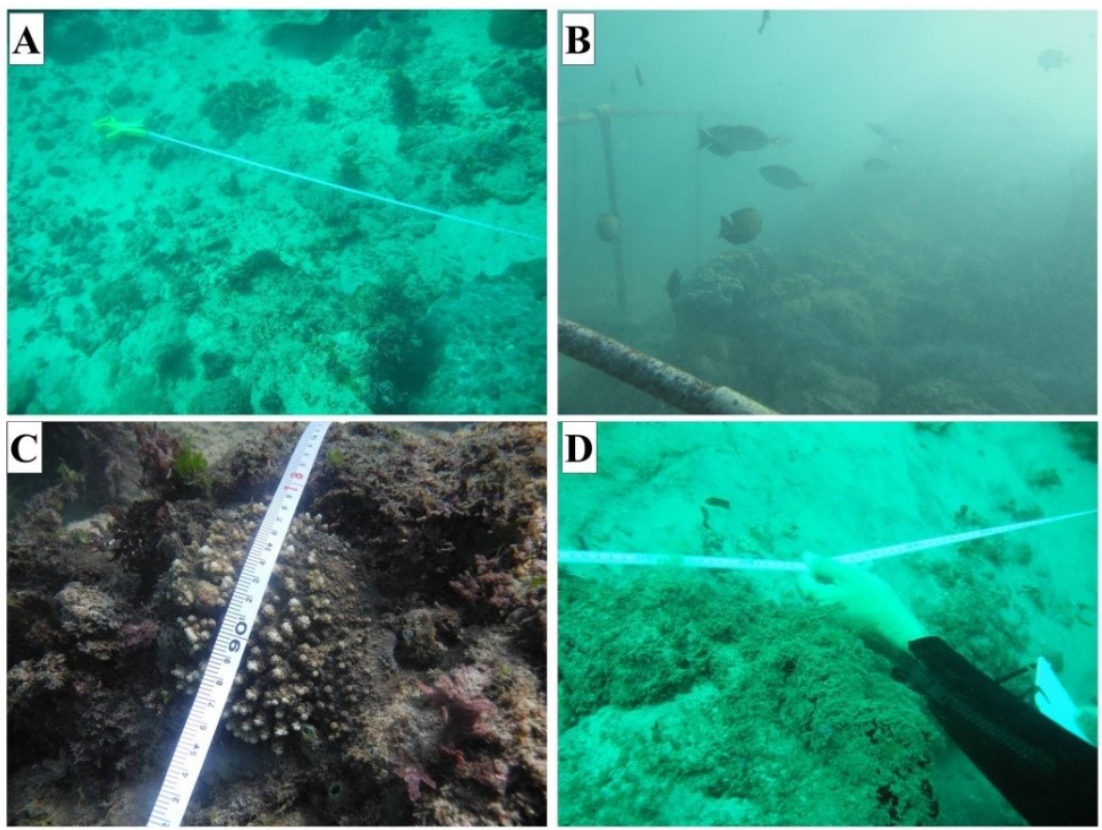

Figure 2. Environmental condition of coral reef in the Tanjung Benoa waters

\subsection{Suitability analysis of Tanjung Benoa waters for dive tourism}

The suitability analysis showed that almost all parameters were in the same score, except for the coral fish species. The score of water visibility at all sites was quite low (10\%). The number hard coral live and coral lifeform score were not different among all sites $(0$ and 6 , respectively). Water depth and water current velocity at all sites also showed a similar score ( $3 \mathrm{~m} / \mathrm{s}$, respectively). The only different value was shown by coral fish parameter. The highest score was shown at Site 3. Based on these results, it can be concluded that there was no big difference in terms of overall score among all sites, which resulted into index of ecotourism suitability of 40.74 to $42.59 \%$. This result suggests that all of the sites in the Tanjung Benoa waters included into "appropriate conditional" category.

Table 6. Dive tourism feasibility in the Tanjung Benoa Waters

\begin{tabular}{|c|c|c|c|c|c|}
\hline \multirow{2}{*}{ Parameter } & \multirow{2}{*}{ Score } & \multicolumn{4}{|c|}{ Site } \\
\hline & & 1 & 2 & 3 & 4 \\
\hline Water visibility & 5 & 10 & 10 & 10 & 10 \\
\hline Hard coral live (HCL) & 5 & 0 & 0 & 0 & 0 \\
\hline Coral lifeform & 3 & 6 & 6 & 6 & 6 \\
\hline Coral fish species & 3 & 0 & 0 & 1 & 0 \\
\hline Water depth & 1 & 3 & 3 & 3 & 3 \\
\hline Water current & 1 & 3 & 3 & 3 & 3 \\
\hline Total & 18 & 22 & 22 & 23 & 22 \\
\hline STI & & 40,74 & 40,74 & 42,59 & 40,74 \\
\hline Suitability level & & $\begin{array}{l}\text { Appropriate } \\
\text { conditional }\end{array}$ & $\begin{array}{l}\text { Appropriate } \\
\text { conditional }\end{array}$ & $\begin{array}{l}\text { Appropriate } \\
\text { conditional }\end{array}$ & $\begin{array}{l}\text { Appropriate } \\
\text { conditional }\end{array}$ \\
\hline
\end{tabular}




\section{Discussion}

The suitability study for dive tourism is usually initiated by arranging a scoring matrix for several kinds of environmental factors. The selection of these environmental factors is carried out based on the impact on that environmental condition. The most important environmental factors for dive tourism are visibility and life-coral reefs (HCL) [17]. Water visibility is known to be most crucial factors because it represents the sunlight penetration into the water. Coral reefs need a certain water visibility to ensure their suitable life in their habitat [21]. The environmental factors influencing the dive tourism are divided into two types: human-influenced and natural factors [7]. The human-influenced factors related to the dive tourism includes water visibility, coral reef diversity, and coral fish. The natural factors associated with the dive tourism consists of water depth and water current.

The suitability analysis showed that Tanjung Benoa waters were categorized as appropriate conditional with the value of Suitability Index from 40,74 to 42,59\%. Tanjung Benoa waters seem to be less appropriate than Berhala island waters in Serdang Bedagai Regency, North Sumatera Province (Suitability index: 74,0\%) [1, 13]. The low suitability rate in the Tanjung Benoa is related to the low coral reef coverage, number of life form, and abundance of coral fish species found in the location.

This study is corresponding to other studies that the low suitability rate of several areas (Pasir Putih, Penampang Island, Battoa Island, and Salama Island) is caused by the low coral reef coverage $[2,22]$. The low coral reef coverage in the Tanjung Benoa might be related to the low water visibility in the location (Table 5). The optimal water visibility for coral life is $100 \%$ [6]. The high antrophogenic activities in the land might transfer a high number of both suspended and particulate materials to the Tanung Benoa waters, causing low water visibility $[5,17]$. These materials inhibit the penetration of sunlight in the water and disturb the growth of coral reefs [3]. Another factor related to the low coral coverage in the Tanjung Benoa waters is the high rate of water current velocity. The optimal current speed for the coral life ranged from 0 to $0,15 \mathrm{~m} / \mathrm{s}$ [18]. Water current is responsible for the sedimentation from terestrial area. Sediment particles cover the polyps of the coral and lead to increase their mortality [7].

\section{Conclusions}

The research shows that Tanjung Benoa waters are determined as appropriate conditional for dive tourism (STI $=40,74$ to 42,59 ). The low water visibility, coral reef coverage, and coral fish species abundance might be the most important factor causing this condition.

Author thank to Education Fund Management Agency (Lembaga Pengelola Dana Pendidikan -LPDP) for providing the doctoral scholarship during this study. Author also thank to Faculty of Fisheries and Marine Science in Universitas Brawijaya and Udayana University for all facilities served during this study.

\section{References}

1. A. Syahputra, Yunasfi, A. Suryanti, J. Aqua coast marine. 12 (2016)

2. A. Bahar, R. Tambaru, Analisis kesesuaian dan daya dukung kawasan wisata bahari di Kabupaten Polewali Mandar (Department of Marine Sciences and the Faculty of Fisheries UNHAS, 2010)

3. A. B. T. Prasetyo, L. P. S. Yuliadi, S. Astuty, D. J. Prihadi, Jurnal Perikanan dan Kelautan 9 (2018) 
4. A. J. Dartnall, M. Jones, ASEAN-Australia Cooperative Program On Marine Science Handbook (Townsville: Australian Institute of Marine Science, 1986)

5. A. R. As-Syakur, D. B. Wiyanto, Trunojoyo University Marine Journal 9 (2016)

6. D. B. Wiyanto, Journal of Marine and Aquatic Sciences (JMAS) 2 (2016)

7. Dedi, N. P. Zamani, T. Arifin, Jurnal Kelautan Nasional 11 (2017)

8. E. D. Gomez, H.T. Yap, Growth of Acropora pulchra (Unesco Publisher, Jakarta, 1984)

9. E. F. Ardiansyah, Hartoni, L. Litasari. Maspari Journal 5 (2013)

10. F. Yulianda, Ekowisata bahari sebagai alternatif pemanfaatan sumber daya pesisir berbasis konservasi (Departemen MSP FPIK, IPB, Bogor, 2007)

11. H. I. Duke, S. R. Widyastuti, S. Hadisaputro, S. Chasani, Jurnal Kesehatan Masyarakat Indonesia 12 (2017)

12. H. Lelloltery, S. Pudyatmoko, C. Fandell, M. Baiquni, Biodiversitas 19 (2018)

13. L. Noviama, H.A. Arifin, L. Adrianto, Kholil, International Journal of Scientific \& Technology Research 2 (2018)

14. M. Hutomo, M. K. Moosa, Indian Journal of Marine Sciences 34 (2005)

15. M. Kulbicki, J. Ferraris. Secretariat of the Pacific Community Noumea, New Caledonia (2002)

16. N. Hilmi, A. Safa, S. Reynaud, S. Allemand, Topics in Middle Eastern and African Economies in Proceedings of the Middle East Economic Association 14 (2012)

17. P. Schuhmann, R. Skeete, R. Waite, P. B. Skeete, J. Casey, H. A. Oxenford, D. A. Gill, MDPI, Water 11 (2019)

18. R. Dahuri. Keanekaragaman hayati laut: aset pembangunan berkelanjutan Indonesia (PT. Gramedia Pustaka Utama, Jakarta, 2003)

19. R. H. Kuiter, T. Tonozuka. by Zoonetics. Australia (2001)

20. S. C. English, V. Wilkinson, Baker, Survey manual for tropical marine resources (Australian Institute of Marine Science, Townsville. Australia, 390, 1997)

21. Y. Guan, S. Hohn, A. Merico. PLoS ONE 10 (2015)

22. Y. Johan, F. Yulianda, R. Kurnia, I. Muchsin. International Journal of Sciences: Basic and Applied Research (IJSBAR) 36 (2017) 